\title{
CHALLENGES BEFORE E-GOVERNANCE AND CUSTOMER RELATIONSHIP MANAGEMENT - A REVIEW
}

\author{
Sambhaji D. Kadam ${ }^{1}$, Dr. Sanjay Aswale ${ }^{2}$
}

Abstract-People centric or customer centric process to satisfy them is known as Customer Relationship Management. .CRM is often seen as a key element in delivering customer-centric services. E-governance is the organic combination of information technology and government management function. With the development of information technology, government has been upgrading from management-oriented mode to service-oriented one. Therefore CRM is a business strategy to provide comprehensive service from all public organizations i.e e-governance. This paper is focusing on the relationship between e-governance and customer relationship management and its challenges. It is concluded that Customer Relationship Management (CRM) and e-governance is services to satisfy the customer or end users. In the era of Information Technology the usage e-communication devices is growing very fast, Indian government as well as all sectors of the economy is making many efforts to provide services to their beneficiaries through e-Governance. They are spending a lot of money on Customer relationship management as well as e-Governance projects but still there is problem of coverage of all the sectors or areas of our country. Unawareness in people, local language of the people of a particular area, privacy for the personal data of the people etc. are main challenges which are responsible for it. So there is need to make the people aware about the e-Governance activities so that people may take full advantage.

Key Words: e-governance, Customer Relationship Management, ICT

\section{INTRODUCTION:}

The use of Information and Communication Technologies (ICTs) to provide citizens and organisations with more convenient access to the government's services and information is known as e-Governance or "electronic Governance." Information and Communication Technology (ICT) includes the electronic devices which directly communicated to the root level or beneficiaries that is internet. It helps to improve the delivery of services. It is not only government to people but also in all sector of the economy. ICT and e-governance is two sides of a coin. The use of ICT not only delivers the services faster but also brings more transparency. Thus the transparency as well as faster service is also e-governance. Both are the satisfaction of the beneficiaries. If we consider the term customer satisfaction it is also part of e-governance. In this context this paper focuses on the relationship between e-governance and customer relationship management and its challenges.

\section{REVIEW OF LITERATURE:}

The review has taken of various authors work done in this concept that enable to understand the subject in detail. As we know that Customer Relationship Management Customer relationship management (CRM) is a process of identifying, attracting, developing and maintaining successful customer relationships to induct and retain customers who are beneficial to the organization. CRM is a techniques and also the complete set of processes and technologies for managing relationships with their customers, associates. All the trade, business, service and concerns are the part of CRM communication process. So the e-governance is an important part of the effective implementation of CRM. In this process we find out the role of CRM and e-governance by reviewing the work of following authors:

Sohrabi, \& Khanlari, 2010- The techniques of CRM has different meaning for different people.

Peppers \& Rogers, 2011 - they have explained that the techniques of CRM is just like analysis of customer information which is analysed by utilizing the (ICT) Information Communication Technologies

King \& Burgess, 2008 - has explained in his study that the process of CRM contributes not only to the concerns but also to the customers. As both of them regularly updated with the CRm and e-governance.

Su, Tsai \& Hsu, 2010 - He has explained in his study that CRM is final aim to achieve with organizing available resources effectively. and it is also known as e-governance.

\section{STATEMENT OF PROBLEM:}

As we know that literacy level is very low and most of the people are living below poverty line, it is very much difficult to provide its services to such citizens via means of internet in developing countries like India. Even the e-Readiness

\footnotetext{
${ }^{1}$ Research Scholar, Department of Commerce, SCS College Omerga

${ }^{2}$ Research Guide \& Head, Commerce SCS College, Omerga
} 
Rank of India is very low. E-readiness is defined as the ability to use information and communication technologies to develop one's economy and welfare. It is find that e-Readiness rank of India was 69 with the score of 3.89 out of 10 as per Global Information Technology Report 2012. India was placed at 91st position in the recently released 2016 (Networked Readiness Index (NRI) by the Geneva-based World Economic Forum). Singapore is first while Finland is second. Thus, India was ranked the lowest. The position of India has come down for the fourth consecutive year in a row, from 89th in $2015,83 \mathrm{rd}$ in 2014 and 68th in 2013. India's performance in terms online services is $57^{\text {th }}$ and allowing eparticipation is $40^{\mathrm{th}}$.

Thus the use of Information and Communication Technology in India is very low. Being a rural India, Agrarian India living in remote area many other factors like privacy and security related to user's personal information, media, connectivity etc. are major challenges for the implementation of e-Governance in India.

\section{OBJECTIVES OF THE STUDY:}

The study has following objectives

1. To study the e-governance system in India

2. To understand the relationship between CRM and e-governance

3. To know the challenges before e-governance and Customer Relationship Management

\section{METHODOLOGY OF THE STUDY:}

The secondary data is used in this paper. It includes the published sources like Journal and articles.

\section{CUSTOMER RELATIONSGHIP MANAGEMENT (CRM):}

Customer Relationship Management (CRM) today is very important for institution that aims to manage the relationship between citizens and administrators. Government institutions need to identify the problems of citizens and enhance the cohesion in relationships with citizens. A good customer relationship is the key to success. The use of customer relationship management systems in government is becoming significantly important for increasing citizen life time value. CRM e-government system is the systematic care of a business relationship between the institution and citizens. A new vision of government system in which the citizens is the central subject opens up new opportunities that include customization and adaptation to citizens' needs and preferences. Given the possibility of dissemination of information to many users, social computing can play important role in improving the e-government process. Many social networks formed groups for government purposes. This paper discusses possible solutions for improving relations between citizens and government institutions in the process of e-government through social media.

\section{CRM and e-GOVERNANCE :}

Every business strategy whose outcomes optimize profitability, revenue and customer satisfaction by fostering customer satisfying behaviours and implementing customer-centric processes is known as Customer Relationship Management. CRM is often seen as a key element in delivering customer-centric services. Today CRM solutions are often implemented as a cloud computing service. Cloud computing refers to providing and using computational resources via the Internet. It enables the access to technology in the form of service on demand. Services and data coexist in shared and dynamically scaled set of resources. E-government is the organic combination of information technology and government management function. With the development of information technology, government has been upgrading from management-oriented mode to service-oriented one. Therefore, government CRM is a business strategy to provide comprehensive service from all public organizations.

\section{CHALLENGES FOR E-GOVERNANCE}

There are a large number of obstacles in implementation of e-Governance in India. These challenges are as under

\section{Challenges of Language Barrier:}

India is a country where people with different cultures and different religions live. People belonging to different states speak different languages. The diversity of people in context of language is a huge challenge for implementing eGovernance projects as e-Governance applications are written in English language. And also, English may not be understandable by most of the people. Therefore, it becomes a challenge for the government to write e-Governance applications which are to be implemented for the whole nation in more than one language so that these may be acceptable to the users of a particular language.

\section{Challenges of Illiteracy:}

Literacy can be defined as the ability to read and write with understanding in any language. A person who can merely read but cannot write cannot be considered as literate. Any formal education or minimum educational standard is not necessary to be considered literate. Literacy level of India is very low which is a huge obstacle in implementation of eGovernance projects. Illiterate people are not able to access the e-Governance applications; hence the projects do not get much success.

\section{Challenges of Lack of IT Literacy:}

Much of the Indian people are not literate and those who are literate, they do not have much knowledge about Information Technology (IT). Most of the people in India are not aware about the usage of Information Technology. So, 
in India, having such low level of IT literacy, how can e-Governance projects be implemented successfully? We can say that IT illiteracy is a major obstacle in implementation of e-Governance in India. So, first of all Indian people must be made aware about the usage of Information Technology.

\section{Challenges of Use of ICT}

Users of e-Governance applications are often non-expert users who may not be able to use the applications in a right manner. Such users need guidance to find the right way to perform their transactions. Therefore, government websites must be user friendly so that more and more.

\section{Challenges of Accessibility:}

Services are not accessible easily: The concept of e-Governance is claiming for increased efficiency and effectiveness of the government, but these goals will be achieved only if the service will be available to the 100 per cent of the citizens. So, every service should be accessible by anybody from anywhere and anytime. It is said that there are 90 per cent of the people are using e-media like mobile as a communication device. Even if the users of Internet are growing there is question of connectivity, reachability, and accessibility. As still there is a major part of Indian population which is not able to access e-Governance activities for variety of reasons, e.g. some people may have limited access to Information and Communication Technologies and devices. Therefore, government has to provide internet access through public terminals as a part of their universal access efforts.

\section{Challenges of Communication:}

Lack of communication between different departments of government may be its major cause. Therefore, the information that resides within one department has no or very little meaning to some other department of the government.

\section{Challenges of awareness in people:}

Most of the Indian people are not aware of the benefits of eGovernance services. Even the government do not pay much attention to make the people aware about e-Governance activities. Unawareness is a major challenge in the implementation of e-Governance projects.

\section{Challenges of Interoperability:}

Interoperability is the ability of systems and organizations of different qualities to work together. The e-Governance applications must have this characteristic so that the newly developed and existing applications can be implemented together.

\section{TO CONCLUDE:}

Thus Customer Relationship Management (CRM) and e-governance is services to satisfy the customer or end users. In the era of Information Technology the usage e-communication devices is growing very fast, Indian government as well as all sectors of the economy is making many efforts to provide services to their beneficiaries through e-Governance. They are spending a lot of money on Customer relationship management as well as e-Governance projects but still there is problem of coverage of all the sectors or areas of our country. Unawareness in people, local language of the people of a particular area, privacy for the personal data of the people etc. are main challenges which are responsible for it. So there is need to make the people aware about the e-Governance activities so that people may take full advantage.

\section{REFERENCES}

[1] Bhatnagar Subhash (2004), e-government from vision to implementation, sage publications, New Delhi.

[2] Dey, Bata K. (2000), "E-governance in India: Problems, Challenges and Opportunities - A Futures Vision", Indian Journal of Public Administration, Vol. XLVI, No. 3.

[3] E-Readiness Ranking (2012), The Global Information Technology Report 2012 by Economist Intelligence Unit.

[4] Gupta, M.P. (2004). Towards E-Government Management Challenges, Tata McGraw-Hill Publishing Company Limited, New Delhi.

[5] Kaushik, P.D. (2004). E-Governance: Government Initiatives in India, in Bibek Debroy, Agenda for improving Governance, Academic Foundation in Association with Rajiv Gandhi Institute for Contemporary Studies, New Delhi.

[6] Kochhar Sameer and Gursharan Dhanjal, (2005). Egovernment Report Card, Yojna, Vol.49, August, New Delhi.

[7] Sohrabi, Babak, Haghighi, Mohammad \& Khanlari, Amir (2010): Customer relationship management maturity model (CRM3): A model for stepwise implementation. International Journal of Human Sciences. Vol.: 7, No.: (1), pp.: 1-20. 